\title{
PENYEDERHANAAN FONOLOGIS DALAM PEMEROLEHAN BAHASA PERTAMA: STUDI KASUS ANAK USIA 1;9
}

\author{
Komang Trisnadewi \\ Universitas Hindu Negeri I Gusti Bagus Sugriwa (IHDN Denpasar) \\ kmgtrisna@yahoo.com
}

\begin{abstract}
ABSTRAK
Penelitian ini bertujuan untuk mengetahui ujaran yang dapat dihasilkan seorang anak serta proses penyederhanaan yang terjadi pada ujaran yang dihasilkan. Subjek penelitian ini adalah anak kembar perempuan dengan usia 1 tahun 9 bulan. Penelitian ini menggunakan metode observasi, yaitu peneliti mengamati kedua anak tersebut, melakukan perekaman serta melakukan pencatatan terhadap kata-kata yang diujarkan. Peneliti ikut serta dan berpartisipasi dalam kotak langsung dengan anak-anak tersebut. Selanjutnya, data yang telah diperoleh dalam bentuk rekaman dilakukan proses transkripsi ke dalam bentuk tulisan. Daftar tulisan yang telah diperoleh kemudian diindentifikasi untuk mengetahui proses penyederhanaan yang terjadi dengan membandingkan dengan ujaran yang seharusnya menurut kamus dan teori penyederhanan dalam pemerolehan Bahasa. Data yang telah dianalisis selanjutnya disajikan dalam bentuk tabel dan juga dipaparkan dengan kalimat sehingga nantinya dapat ditarik simpulan. Hasil penelitian menunjukkan bahwa terjadi beberapa proses penyederhaaan terhadap ujaran yang dihasilkan yang berupa substansi, reduksi dan penyederhanaan struktur kata. Dilihat dari bunyi yang dihasilkan, kedua anak ini mampu untuk menghasilkan fonem /m/, /k/./t/, /d/, /p/,/n/, /b/, /a/, /o/,/i/, /a:/, /e/.
\end{abstract}

Kata kunci: anak usia 21 bulan; pemerolehan bahasa pertama; penyederhanaan fonologis

\begin{abstract}
This research was conducted to determine the utterances that can be produced by a child and the simplification process that occurs in the utterances produced. The subject of this study is female twins aged 1 year 9 months. This study uses the method of observation, the researcher observes the two children, records and takes note the words spoken. The researcher participates in communicating with these children. Furthermore, the data that has been obtained in the form of records is transcribed into written form. The list of writings that have been obtained is then identified to find out the simplification process that occurs by comparing with the utterances that should be according to the dictionary and simplification theory in language acquisition. Data that has been analysed are then presented in tabular form and also presented with sentences. The results showed that there were several simplification processes for the utterances produced in the form of substance, reduction and word structure simplification. These two children are able to produce $/ \mathrm{m} /, / \mathrm{k} / . / \mathrm{t} /, / \mathrm{d} /$, $/ \mathrm{p} /, \mathrm{n} /, / \mathrm{b} /, / \mathrm{a} /, / \mathrm{o} /, / \mathrm{i} /, / \mathrm{a}: /, / \mathrm{e} /$.
\end{abstract}

Keywords: 21 months old child; first language acquisition; phonological simplification

\section{PENDAHULUAN}

Pemerolehan bahasa pertama sangat penting karena saat inilah untuk pertama kalinya bayi mencoba untuk merespon dan mengekspresikan segala sesuatu yang ada dalam pikirannya. Selain itu, pemerolehan bahasa pertama ini juga akan berpengaruh pada pemerolehan bahasa beikutnya. Pemerolehan bahasa pertama sangat erat hubungannya dengan perkembangan sosial anak. Pada dasarnya proses pemerolehan bahasa pada anak sedikit demi sedikit dibangun seiring dengan rangsangan dari lingkungan. Bayi bisa mengujarkan sesuatu atau pun merespon sesuatu bila ada rangsangan dari luar, yakni 
lingkungan terutama orang tuanya, sehingga ada yang dapat didengar, dilihat, dan bahkan ditiru oleh bayi. Hal tersebut juga selaras dengan penelitian yang dilakukan oleh Suardi dkk yang mengatakan bahwa faktor ligkungan mempengaruhi pemerolehan bahasa pada anak dalam aspek fonologi khususnya lingkungan keluarga. Hal tersebut dibuktikan dengan banyaknya jumlah kosakata yang mereka dapatkan dari lingkungan keluarga dan sekitarnya (Suardi et al., 2019).

Namun tidak dapat dipungkiri bahwa faktor bawaan (gen/bersifat biologis) juga berperan karena berisi kemampuan atau bakat seorang anak dalam berbahasa. Pemerolehan bahasa dapat diturunkan sejak anak itu lahir dan perlu ditingkatkan oleh orang tua selama masa kanakkanaknya yang artinya sejak lahir, ada anak yang memang memiliki bakat bahasa, tetapi ada pula bakat yang diperoleh dari hasil perkembangan baik di lingkungan keluarga atau sekolah. Teori ini dikemukakan oleh tim nativisme.

Selain diri anak itu sendiri, setidaknya ada tiga faktor yang juga sangat berpengaruh dalam pemerolehan bahasa. Ketersediaan masukan adalah faktor pertama. Masukan yang dimaksud adalah masukan yang bersifat kebahasaan. Semakin banyak stimuli yang diterima anak dari para interlokutornya, maka makin bertambah pula kemampuan kognitif dan kebahasaannya. Faktor kedua adalah keterpajanan anak terhadap lingkungan. Segala situasi yang ada di sekitar anak perlu untuk diperkenalkan. Dengan semua pajanan yang ada, diharapkan kemampuan anak dalam menganalisis konsep dan konteks yang ada di sekitarnya akan berkembang dengan baik. Faktor ketiga yang tidak kalah penting adalah interaksi. Sebuah penelitian di Amerika Serikat mengungkapkan bahwa anak yang cerdas adalah anak yang sering diajak "mengobrol" oleh orang- orang di sekitarnya. Obrolan tersebut merupakan salah satu jenis interaksi antara anak dengan dunia di luar dirinya (Budhiono, 2011). Kebanyakan kata-kata yang mampu diujarkan oleh anak menggambarkan kegiatan yang dilakukan di dalam kehidupan anak tersebut (Palenkahu, 2009).

Bahasa bukan hanya merupakan sistem tunggal, melainkan dibangun oleh sejumlah subsistem diantaranya subsistem fonologi, sintaksis, dan leksikon (Chaer, 2009). Pemerolehan bahasa itu sendiri meliputi pemerolehan sintaksis, semantik, dan juga fonologi yang diperoleh oleh anak dan berkembang secara bersama, namun dalam pengkajiannya, komponen-komponen linguistik tersebut dilakukan secara terpisah.

Penelitian tentang pemrolehan bahasa menjadi hal yang menarik bagi para pakar linguistik yang terbukti dari banyaknya ditemukan penelitian tentang pemerolehan bahasa hingga sekarang. Berdasarkan penelitian pemerolehan bahasa, khususnya produksi bahasa Bali, dikatakan bahwa kompetensi linguistik anak pada usia $4-6$ tahun berada pada kompetensi linguistik menjelang tata bahasa yang diidealkan penutur dewasa (Arnawa, 2009). Penelitian lain mengatakan bahwa pada usia 2 tahun 10 bulan telah mampu memproduksi 18 fonem konsonan, ditambah 8 variasi , 6 fonem vocal, 2 variasi dan 5 diftong (Anggaira, 2016). Di sisi lain, hasil penelitian oleh Arnama menunjukkan bahwa kompetensi linguistik pada produksi bahasa Bali anak usia 4-6 tahun berada pada kompetensi linguistik menjelang tata bahasa yang diidealkan penutur Bahasa (Arnawa, 2009).

Penelitian mengenai pemerolehan leksikon pada anak usia 3.6 tahun juga telah dilakukan. Banyaknya kelas kata yang telah diucapkan diketahui berjumlah 7 jenis kelas kata dalam bahasa Indonesia dan bahasa Jawa, yang meliputi kata benda, kata sifat, kata keterangan, kata bilangan, kata kerja, kata ganti, dan kata pelengkap. Subjek penelitiannya adalah seorang anak yang memiliki kemampuan bahasa ibu bahasa Jawa. Dalam hal ini anak tersebut sudah mampu mengucapkan kata sebanyak 237 buah (Apriani et al., 2019). Penelitian yang dilakukan oleh Saputri memiliki hasil bahwa pemerolehan bahasa pada anak 3 tahun pada tataran morfologi berupa prefiks dan sufiks sedangkan pemerolehan sintaksis meliputi kalimat deklaratif dan imperative (Saputri, 2018). Sedangkan, pemerolehan bahasa untuk tataran morfologi pada anak usia 19 bulan telah mampu juga untuk memproduksi kata tetapi masih dalam bentuk kata tunggal dan masih sering salah ucap. Berdasarkan jenis katanya, kata-kata yang dihasilkan termasuk ke dalam kata benda 
dan kata sifat. Memasuki usia 24 bulan (2 tahun) seorang anak sudah mampu memproduksi kata-kata yang lebih banyak dan tidak hanya sebatas satu atau dua kata saja melainkan lebih dari itu dimana kata benda adalah kata yang masih mendominasi. Setelah itu, jenis kata yang mengalami perkembangan kosakata adalah jenis kata kerja dan kata sifat (Andini, 2018).

Tahapan dalam proses pemerolehan bahasa pada seorang anak merupakan suatu hal yang menarik terutama pada kompetensi fonologi. Sebagai salah satu bidang linguistik, fonologi adalah ilmu yang menyelidiki bunyi-bunyi bahasa menurut fungsinya (Kridalaksana, 1984). Komponen fonologi adalah sistem bunyi suatu bahasa. Komponen ini bertugas mengubah struktur luar sintaksis menjadi representasi fonetik yaitu bunyi-bunyi bahasa yang kita dengar yang diucapkan oleh seorang penutur (Chaer, 2009).

Ingram mengatakan bahwa sebelum anak memperoleh sistem fonologi orang dewasa, anak menciptakan strukturnya sendiri yang kemudian diubah-ubah seiring dengan pengetahuan mengenai sistem orang dewasa yang dimiliki olehnya semakin baik (Ingram, 1989). Pada subsistem fonologi, dalam proses pemerolehan bahasa tersebut, sebelum anak berhasil untuk memproduksi bahasa (khusunya fonem/bunyi), adapaun beberapa tahapan yang dilalui. Dalam prosesnya, anak tersebut tidak akan langsung bisa untuk mengucapkan ataupun menghasilkan bahasa secara sempurna. Bunyi-bunyi yang didengar oleh bayi secara berulang-ulang akan ditangkap oleh si bayi yang kemudian akan diproses di dalam otaknya, yang memang belum berkembang secara sempurna. Dalam hasilnya, yaitu pengucapan bahasa, tentu juga tidak akan sesempurna yang didengar oleh bayi, karena alat ucapnya yang belum sempurna. Kata atau bunyi yang dihasilkan akan tidak sepenuhnya sama persis dengan yang didengar. Perkembangan fonologi ini melalui proses asimilasi dan akomodasi yang berlangsung secara terus-menerus (menurut teori Piaget) dengan cara mengubah strutur untuk menyamakan dengan kenyataan (Piaget, 2001).

Ingram menegaskan bahwa kita harus mengakui adanya ketiga perangkat perkembangan fonologi yaitu kata orang dewasa, sistem kanak-kanak dan kata kanakkanak. Terdapat subtahap pada tahapan pemerolehan fonologi yaitu tahap vokalisasi pengucapan dan tahap primitif (Ingram, 1979). Tahap vokalisasi pengucapan adalah tahap yang dimulai dengan mendekut sebelum katakata pertama muncul yang terjadi ketika bayi berumur empat bulan. selanjutnya adalah mebabel. Menurut Ingram, membabel ini bukanlah kegiatan yang tidak ada maknanya atau semaunya, melainkan merupakan sebuah kegiatan agak teratur, dan maju secara terus menerus. Membabel ini juga bukan merupakan suatu latihan, melainkan menjadi bagian yang ada hubungannya dengan seluruh proses pemerolehan fonologi (Ingram, 1979).

Sedangkan pada tahap fonologi primitif, muncul tahap satu kata (holofrasis) dalam pemerolehan sintaksis anak. Tahap ini adalah tahapan yang belum produktif karena anak belum memperoleh rumus fonologi yang semestinya. Pada tahap pengeluaran (tahap proses yang aktif), yang dimulai ketika anak berusia satu tahun setengah (1:6), ada dua peristiwa penting yang terjadi di dalamnnya, yaitu: cepatnya pertumbuhan kosakata serta kemampuan anak untuk mengeluarkan ucapanucapan yang terdiri dari dua kata. Pada tahap ini anak memiliki kemampuan untuk menentukan sendiri bunyi-bunyi ucapan yang dipakainya untuk menyatakan perbedaan makna. Tahap ini terjadi hingga anak berusia tiga tahun enam bulan atau sampai empat tahun. Pemerolehan setiap bunyi anak terjadi secara perlahan dan berangsur. Ucapan anak selalu berubah-ubah antara mengucapkan kata yang benar dan tidak benar, namun menuju kearah kemajuan hingga mencapai ucapan seperti orang dewasa. Melalui beberapa proses penyederhanaan umum dengan melibatkan kelas bunyi, pemerolehan fonologi anak terjadi. Proses-proses tersebut meliputi proses substansi, asimilasi, dan proses struktur suku kata (Ingram, 1979).

Berbeda dengan penelitian mengenai pemerolehan bahasa yang sebelumnya atau yang sudah pernah dilaksanakan, penelitian ini lebih menitik beratkan pada proses penyederhanaan bahasa yang terjadi dalam proses pemerolehan bahasa pertama anak dengan mengambil studi kasus anak berusia satu tahun sembilan bulan, penelitian ini bertujuan selain untuk mengetahui fonem yang 
mampu dihasilkan oleh anak berusia 1 tahun 9 bulan, penelitian ini juga dilakukan untuk mengetahui proses penyederhanaan yang terjadi pada ujaran yang dihasilkan dan sekaligus untuk mengetahui adakah ada kata yang dapat diujarkan secara sempurna sehingga nantinya dengan penelitian ini akan mampu memberikan masukan terhadap proses pemerolehan bahasa pertama anak, khususnya usia $1 ; 9$.

\section{METODE}

Penelitian ini dilakukan pada sebuah keluarga yang tinggal di area Denpasar, tepatnya berada di Jalan Tukad Petanu. Keluarga ini terdiri dari pasangan suami istri dan dua orang anak perempuan yang mana keduanya merupakan anak kembar dengan nama panggilan Anda dan Indi. Penelitian ini dilakukan saat keduanya berusia 1 tahun 9 bulan. Keluarga ini memilki status sosial yang cukup baik. Kedua orang tuanya berpendidikan S1 dan keduanya menguasai bahasa Inggris, Indonesia, dan Bali dengan baik. Karena kesibukan yang memang dialami oleh pasangan suami istri ini, maka waktu untuk berkumpul antara ayah, ibu, dan kedua anaknya tidak bisa terjadi setiap hari. Namun, dalam hal pengasuhan dan pendidikan anak, salah satu dari kedua orang tuanya harus selalu menemani kedua anak tersebut. Mengenai pengasuhan dan pendidikannya, Anak tersebut memang diajak bekomunikasi menggunakan bahasa Inggris, mengingat ibunya adalah seorang guru guru bahasa Inggris di sekolah Menengah Atas di Denpasar dan ayahnya adalah seorang pekerja di bidang pariwisata. Namun terkadang untuk beberapa kesempatan, orang tuanya juga menggunakan bahasa Indonesia dan Bahasa Bali dengan intensitas yang tidak teralalu sering. Apapun yang dilakukan oleh orang tuanya, sebisa mungkin diberitahukan kepada anak-anaknya dengan harapan nantinya anak mereka akan cepat mengerti dan mengenali lingkungan sekitar. Terkadang orang tuanya memang secara langsung mengajarkan sebuah kata kepada anaknya, seperti misalnya menunjukkan sebuah buku dan mengatakan [bok]. Waktu dari kedua anak tersebut memang banyak dihabiskan di rumahnya karena kurangnya waktu orang tua untuk pergi bersama. Waktu penelitian ini adalah sekitar 2 bulan. Waktu 2 bulan ini, penulis tidak secara terus menerus berada pada keluarga ini, pertemuan hanya mencakup beberapa kali dan selebihnya adalah menggali informasi dari orang tuanya. Kedatangan penulis biasanya dilakukan pada siang hari setelah makan siang, dimana pada saat itu, kedua anak itu sedang bermain.

Data pada penelitian ini adalah data primer. Data tersebut diambil langsung menggunakan metode observasi, yaitu peneliti mengamati pola pendidikan yang dilakukan orangtua terhadap anak-anaknya dan melakukan pengamatan terhadap kedua anak tersebut, melakukan perekaman serta melakukan pencatatan terhadap kata-kata yang diujarkan. Metode observasi dilakukan karena peneliti ingin mendapatkan data secara natural dan tidak terlewatkan. Mengingat subjek penelitian adalah anak berusi $1 ; 9$, data yang dibutuhkan bisa dihasilkan kapan saja tanpa waktu yang pasti. Peneliti ikut serta dan berpartisipasi dalam kotak langsung dengan anak-anak tersebut. Sesekali peneliti mengucapkan suatu bunyi dengan harapan anak-anak tersebut mengulanginya atau bahkan mengucapkan bunyi baru. Hal ini dilakukan sebagi bentuk pancingan kepada subjek penelitian agar menghasilkan ujaran yang diperlukan sebagai data. Penulis mendata kata-kata apa saja yang dapat diucapkan oleh kedua anak tersebut dan benda atau hal yang diacu atau dimaksud dengan pengucapan bunyi atau kata tersebut. Panca indra sangat berperan dalam penggunaan metode ini guna menangkap ujaran yang dihasilkan. Selain itu, peneliti juga menggunakn alat bantu rekaman untuk merekam kata yang diujarkan oleh anak-anak tersbut. Peneliti juga tidak lupa menggunakan buku catatan untuk menulis kata yang diucapkan sebagai tambahan data untuk mendukung hasil rekaman. Dikarenaka waktu yang tidak memungkinkan untuk tinggal di keluarga tersebut selama penelitian, maka peneliti juga menggunakan metode wawancara kepada orang tua anak guna meminta bantuan dan informasi dari orang tua terkait kata yang mampu diucapkan oleh anaknya. Pertanyaan yang diajukan adalah terkait kata yang mampu diujarkan oleh anak saat peneliti sedang tidak berada disana. Selain itu, peneliti juga menanyakan informasi terkait cara mendidik 
anak, cara menstimulasi anak agar mau berbicara dan kondisi kesehatan anak khususnya alat produksi suara.

Selanjutnya, data yang telah diperoleh baik dalam dalam bentuk rekaman, catatan dari peneliti sendiri, maupun tambahan informasi dari orang tua anak digabungkan untuk disaring apabila ada data ganda. Data berupa rekaman dilakukan proses transkripsi ke dalam bentuk tulisan. Daftar tulisan yang telah diperoleh kemudian diindentifikasi untuk mengetahui proses penyederhanaan yang terjadi. Proses identifikasi ini dilakukan peneliti dengan menganalisis setiap bunyi yang dihasilkan baik vokal maupun konsonan dengan membandingkannya dengan ujaran yang diajarkan oleh orang tua anak serta teori penyederhanan dalam pemerolehan Bahasa. Proses penyederhaan didapat dengan menganalisis bunyi konsonan yang diucapkan berdasrakan bergetar tidaknya pita suara, tempat artikulasi dan cara artikulasi. Huber dkk mengatakan bahwa untuk konsonan biasanya menggunakan tiga kategori yaitu voicing, manner, and articulation (Huber et al., 2009). Sedangkan untuk bunyi vokal dianalisis produksinya berdasarkan tinggi rendahnya lidah, maju mundurnya lidah, dan bulat pipihnya bibir. Disampaikan oleh Huber dkk bahwa terdapat tiga kategori yaitu vowel height, vowel location dan lip positions yang digunakan dalam produksi konsonan Bahasa Inggris (Huber et al., 2009).

Data yang telah dianalisis selanjutnya disajikan dalam bentuk tabel yang berupa tabel ujaran anak serta table penyederhanaan ujaran yang terjadi. Kalimat deskripsi juga digunakan untuk menjelasakan tabel yang ada sehingga nanti bisa ditarik simpulan sesuai dengan tujuan dari penelitian.

\section{PEMBAHASAN}

Pada usia ini, yaitu 1 tahun 9 bulan, kedua anak ini memang memiliki kemapuan dan kata yang sama untuk diucapkan. Kata-kata yang diucapkan sebatas terdiri dari dua suku kata dan tidak melebihi dua suku kata yang memang sebelumnya dimulai dengan mengucapkan satu suku kata saja. Mereka biasanya mengucapkan kata tersebut terhadap suatu benda yang dirujuknya atau menginginkan sesuatu terhadap kata yang diucapkan. Kata-kata yang diucapkan oleh kedua anak tersebut memang sangat dipengaruhi oleh lingkungan. Mereka dapat menghasilkan suatu ujaran melalui peniruan atas bunyi yang didengarnya. Pada kenyataannya, kata-kata yang didengar oleh anak tersebut atau kata yang diucapkan oleh orangtuanya selaku lingkungan si anak memang tidak semuanya terdiri dari dua suku kata, namun anak tersebut mengucapkannya menjadi dua suku kata. Variasi kata yang dihasilkan memang tidak begitu banyak dan memang kata-kata yang dihasilkan erat hubungannya dengan hal-hal atau kegiatan yang berhubungan dengan anak-anak tersebut. Berikut adalah kata-kata yang mampu diucapkan dan memang sering diucapkan oleh kedua anak tersebut berikut arti yang dimaksud oleh anak tersebut.

Tabel 1. Kata yang Dihasilkan Subjek Penelitian

\begin{tabular}{|c|c|c|}
\hline No & Ujaran anak & Makna \\
\hline 1 & [mamak] & Ibu/mama \\
\hline 2 & [toto] & Tomato/ tomat \\
\hline 3 & [dadi] & Dady/ayah \\
\hline 4 & [mama] & Grandma \\
\hline 5 & [papa] & Grandpa \\
\hline 6 & [ao] & Halo \\
\hline 7 & [ti] & Aunty/bibi \\
\hline 8 & [nana] & Banana \\
\hline 9 & [bebi] & Baby/bayi \\
\hline 10 & [nono] & Rhino (nama boneka) \\
\hline 11 & [pi] & Pee/kencing \\
\hline 12 & [didi] & Dede (nama orang) \\
\hline 13 & [ka] & Car/mobil \\
\hline 14 & [bobok] & Tidur \\
\hline
\end{tabular}

Dilihat dari kata yang diucapkan serta hal atau benda yang dimaksud, memang sebagian besar adalah kata dari Bahasa Inggris yang memang disebabkan oleh penggunaan Bahasa Inggris oleh orang tua dari kedua anak tersebut dalam berkomunikasi. Dikonfirmasi juga dengan kedua orang tua anak bahwa kata yang diujarkan anak tersebut yang terdapat pada tabel di atas adalah semua kata yang diajarkan oleh kedua orangtua mereka.

Dari data diatas, dapat dilihat bahwa sesuai dengan teori yang dikemukakan oleh Ingram bahwa proses penyederhanaan dilalui oleh anak dalam pemerolehan fonologi. Ada beberapa 
proses yang terjadi saat penyederhanaan bunyi

yang dapat dilihat pada tabel 2 berikut.

Tabel 2. Proses Penyederhanaan Bunyi

\begin{tabular}{|c|c|c|c|c|}
\hline No & Kata & $\begin{array}{l}\text { Bunyi yang } \\
\text { diajarkan }\end{array}$ & Ujaran anak & Makna \\
\hline 1 & Mamak & [mamak] & [mamak] & kata sapaan lain untuk ibu \\
\hline 2 & Tomato & $\begin{array}{l}\text { [to'ma:tər] } \\
\text { [tə'ma:to] }\end{array}$ & [toto] & buah tomat \\
\hline 3 & Daddy & ['dædi] & [dadi] & ayah, orang tua laki-laki \\
\hline 4 & Grandma & ['grænma:] & [ma:ma:] & nenek, ibu dari ayah atau ibu \\
\hline 5 & Grandpa & ['grænpa:] & [pa:pa:] & Kakek, ayah dari ayah atau ibu \\
\hline 6 & Halo & [halo] & [ao] & halo, ucapan salam untuk menyapa \\
\hline 7 & Aunty & ['a:nti] & [ti] & bibi, adik perempuan dari ayah atau ibu \\
\hline 8 & Banana & $\begin{array}{l}\text { [bə'na:nə] } \\
\text { [bə'na:na] }\end{array}$ & [na:na] & buah pisang \\
\hline 9 & Baby & ['berbi] & [bebi] & bayi, anak yang belum lama lahir \\
\hline 10 & Rino & [rino] & [nono] & nama boneka \\
\hline 11 & Pee & [pi:] & [pi:] & kencing, buang air kecil \\
\hline 12 & Dede & [dede] & [didi] & nama orang \\
\hline 13 & Car & [ka:r] & [ka:] & $\begin{array}{l}\text { mobil, kendaraan roda empat yang } \\
\text { digerakkan oleh tenaga mesin }\end{array}$ \\
\hline 14 & Bobok & [bobok] & [bobok] & tidur (untuk anak-anak) \\
\hline
\end{tabular}

Proses penyederhaan bunyi yang terjadi adalah proses substansi atau penggantian. Ujaran [dadi] yang dihasilkan oleh anak yang merujuk kepada ayah mereka adalah bentuk penggantian atau substansi melalui proses netralisasi bunyi vokal. Ujaran [dadi] adalah bentuk penyederhanaan dari [dædi]. Pada kata tersebut terjadi perubahan vokal [æ] (berdasarkan posisi lidah: vokal depan, berdasarkan ketinggian lidah: vokal rendah dan berdasarkan posisi bibir: tidak bulat) menjadi [a:] (berdasarkan lokasi lidah: vokal belakang, berdasarkan ketinggian lidah: vokal rendah dan berdasarkan posisi bibir: tidak bulat). Kata tersebut adalah kata bahasa inggris yang dipakai untuk menyebutkan nama ayah. Perubahan terjadi karena ketidaksesuiaan posisi lidah yang seharusnya di depan, namun diletakkan di belakang sehingga menghasilkan bunyi yang berbeda.

Proses serupa juga ditemukan dalam pengucapan [didi] yang seharusnya berbunyi [dede]. Kata tersebut adalah sebutan untuk nama orang, yaitu saudara sepupu dari subjek penelitian yang memang sering diucapkan oleh orang tua mereka. Kedua anak ini cenderung untuk mengganti vokal [e] (berdasarkan posisi lidah: vokal depan, berdasarkan ketinggian lidah: vokal tengah dan berdasarkan posisi bibir: tidak bulat) menjadi bunyi vokal [i] (berdasarkan posisi lidah: vokal depan, berdasarkan ketinggian lidah: vokal tinggi dan berdasarkan posisi bibir: tidak bulat). Perubahan terjadi karena ketidaksesuaian ketinggian lidah yang seharusnya tengah, namun diposisikan tinggi.

Kata lain yang mengalami proses substansi adalah kata baby yang seharunya diucapkan /'berbi/, namun oleh subjek peneliti diujarkan [bebi]. Vokal dipthong [eI] (perpindahan dari bunyi terbuka ke bunyi tertutup, dari bunyi vokal depan, tinggi dan tidak bulat menjadi bunyi vokal depan, tengah dan tidak bulat) diganti dengan vokal [e] (berdasarkan posisi lidah: vokal depan, berdasarkan ketinggian lidah: vokal tengah dan berdasarkan posisi bibir: tidak bulat). Perubahan terjadi karena ketidaksesuaian produksi bunyi vokal yang seharusnya bunyi diphthong (dua vokal) menjadi monophthong (satu vokal).

Pada penelitian ini juga ditemukan proses lain pada penyederhanaan kata, yaitu proses penyederhanaan struktur suku kata. Adanya reduplikasi dimana kata panjang disederhanakan menjadi suku kata KV (konsonan vokal) diulang, yaitu pada ujaran 
[mama], [papa], [toto], [nana], [nono]. Ujaran yang dihasilkan oleh anak tersebut mengalami penyederhanaan. Ujaran [mama] dengan rincian bunyi $[\mathrm{m}]$ (berdasarkan bergetar tidaknya pita suara: voiced, berdasarkan tempat artikulasi: bilabial, bersasarkan cara artikulasi: plosive), dan bunyi [a] (berdasarkan lokasi lidah: vokal belakang, berdasarkan ketinggian lidah: vokal rendah dan berdasarkan posisi bibir: tidak bulat ) diujarkan dengan maksud untuk menyatakan grandma. Pada kata tersebut, anak tersebut mengambil suku kata terakhir dan mereduplikasikannya. Kata yang dihasilkan berpola KVKV.

Dengan maksud untuk menyatakan (grandpa), kata yang diujarkan adalah [papa] yang juga mengalami penyederhanaan. Penyederhanaanya adalah dengan mengucapkan hanya suku kata terakhir dan mereduplikasinya sehingga menghasilkan [papa] dengan rincian bunyi [p] (berdasarkan suara: voiceless, berdasarkan templat artikulasi: bilabial, berdasarkan cara artikulasi: plosive) dan [a] (berdarkan posisi lidah: vokal belakang, berdasarkan ketinggian: vokal rendah, dan berdasarkan posisi bibir: vokal tidak bulat).

Ujaran [toto] dengan rincian bunyi [t] (berdasarkan bergetar tidak pita suara: voiceless, berdasarkan tempat artikulasi: alveolar, berdasrkan cara artikulasi: plosive) dan bunyi [o] (berdasarkan lokasi lidah adalah vokal belakang, berdasarkan ketinggian adalah vokal tengah, dan berdasarkan posisi bibir adalah vokal bulat) adalah ujaran yang dihasilkan sebagai hasil penyederhanaan dari kata tomato. Suku kata yang diambil juga suku kata terakhir dan direduplikasi. Pengucapan yang benar dari kata tomato adalah /tə' ma:təo/, namun subjek penelitian tidak menggunakan vokal dipthong $ә \mho$, melainkan menggunakan vokal [o]. Selama hasil observasi, penulis mengamati ternyata orang tua mereka tanpa sadar tidak secara konsisten mengatakan [tə'ma:tər], melainkan terkadang mengatakan [to'ma:to]. Hal ini tentu karena dipengaruhi oleh Bahasa pertama orang tua mereka, yakni Bahasa Indonesia yang memang tidak memliki vokal dipthong /əo/.

Seperti halnya yang lain, reduplikasi suku kata terakhir juga terjadi pada kata "rino" yang diujarkan menjadi [nono] dengan rincian bunyi [n] (berdsarkan bergetar tidaknya pita suara: voiced, berdasarkan tempat artikulasi: alveolar, berdasrkan cara artikulasi: stop) dan bunyi [o] (berdasarkan posisi lidah adalah vokal belakang, berdasarkan ketinggian adalah vokal tengah, dan berdasarkan posisi bibir adalah vokal bulat). Bunyi ini digunakan untuk merujuk suatu benda, dalam hal ini adalah boneka yang bernama Rino.

Pengucapan [nana] yang dihasilkan oleh anak tersebut digunakan untuk merujuk kata banana atau pisang juga mengalami proses reduksi. Bunyi yang diucapkan hanya suku kata terakhir dari kata banana. Selanjutnya bunyi tersebut diulang sehingga menghasilkan [nana] dengan rincian bunyi [n] (bergetar tidaknya pita suara: voiced, berdasarkan tempat artikulasi: alveolar, berdasarkan cara artikulasi: stop) dan bunyi [a] (berdasarkan posisi lidah adalah vokal belakang,berdasarkan ketinggian adalah vokal rendah dan berdasarkan posisi bibir adalah tidak bulat). Sama halnya dengan kata tomato, kata banana juga tanpa sadar dilafalkan berbeda oleh orang tua mereka, terkadang [bə'na:nə] atau [banana]. hal ini tentu berpengaruh pada ujaran yang dihasilkan oleh subjek peneliti.

Kata lain yang juga mengalami proses reduksi yang digunakan oleh anak ini dalam mengucapkan kata adalah pada kata/a:nti/ yang mereka ujapkan dengan [ti] dengan rincian bunyi [t] (berdasarkan bergetar tidaknya pita suara: voiceless, berdasarkan tempat artikulasi: alveolar, berdasarkan cara artikulasi: plosive) dan bunyi [i] (berdasrkan posisi lidah adalah vokal depan, berdasarkan ketinggian adalah vokal tinggi dan berdasarkan posisi bibir adalah vokal tidak bulat). Anak tersebut menggunakan suku kata terakhir, dengan menghilangkan suku kata awal, pada hal ini adalah vokal.

Proses penyederhanaan reduksi yang terjadi pada pengucapan oleh anak kembar tersebut dapat dilihat juga pada pengucapan [ao] dengan rincian bunyi [a] (berdasarkan posisi lidah adalah vokal belakang,berdasarkan ketinggian adalah vokal rendah dan berdasarkan posisi bibir adalah tidak bulat) dan [o] (berdasarkan posisi lidah adalah vokal belakang, berdasarkan ketinggian adalah vokal tengah, dan berdasarkan posisi bibir adalah vokal bulat), dimana yang dimaksud oleh bayi kembar ini adalah kata 'halo'. Mereka 
menghilangkan konsonan dan hanya menyebutkan bunyi vokalnya.

Kata car diujarkan [ka] dengan rincian [k] berdasarkan bergetar tidaknya pita suara: voiceless, berdasarkan tempat artikulasi: velar, berdasarkan cara artikulasi: (plosive), dan [a:] (berdasarkan posisi lidah: vokal belakang, berdasarkan ketinggian: rendah, dan berdasarkan posisi bibir: tidak bulat) oleh subjek peneliti dibandingkan dengan ujaran seharusnya $[\mathrm{ka}:(\mathrm{r})]$.

Namun di antara ujaran yang dihasilkan, ada juga bunyi yang dihasilkan secara sempurna tanpa melalui proses penyederhanaan. Kata yang dimaksud adalah pengucapan [pi:], [mamak], [bobok]. Bunyi [pi:] terdiri dari konsonan [p] (voiceless, bilabial, plosive) dan bunyi [i:] (berdasarkan ketinggian adalah vokal tinggi, berdasarkan posisi lidah adalah depan, dan berdasarkan posisi bibir adalah tidak bulat). Bunyi [mamak] terdiri dari bunyi konsonan [m] (berdasarkan bergetar tidaknya pita suara: voiced, berdasarkan tempat artikulasi: bilabial, berdasarkan cara artikulasi: plosive) dan bunyi [a] (berdasarkan posisi lidah adalah vokal belakang, berdasarkan ketinggian adalah vokal rendah dan berdasrkan posisi bibir adalah tidak bulat) dan konsonan [k] (berdasarkan bergetar tidaknya pita suara: voiceless, berdasarkan tempat artikulasi: velar, berdasarkan cara artikulasi: plosive). Bunyi [bobok] terdiri dari konsonan [b] (berdasarkan bergetar tidaknya pita suara: voiced, berdasarkan tempat artikulasi: bilabial, berdasarkan cara artikulasi: plosive), vokal tengan [o] (berdasarkan posisi lidah adalah vokal belakang, berdasarkan ketinggian adalah vokal tengah, dan berdasarkan posisi bibir adalah vokal bulat)_dan konsonan konsonan [k] (berdasarkan bergetar tidaknya pita suara: voiceless, berdasarkan tempat artikulasi: velar, berdasrakan cara artikulasi: plosive).

\section{SIMPULAN}

Merujuk pada pembahasan di atas, diperoleh simpulan bahwa (1) fonem yang berhasil dihasilkan adalah $/ \mathrm{m} /, / \mathrm{k} /$. /t/, /d/, /p/, /n/, /b/, /a/, /o, /i/, /a:/, /e/. yang merupakan gabungan dari Bahasa Inggris dan Indonesia. Dari fonem tersebut, bunyi konsonan yang berhasil diucapkan berdasarkan bergetar tidaknya pita suara, termasuk dalam voiced dan voiceless. Berdasarkan tempat artiulasi, fonem yang dihasilkan termasuk ke dalam bilabial, velar dan alveolar. Berdasarkan cara artikulasi, fonem yang dihasilkan termasuk ke dalam plosive dan stop. Sedangkan untuk bunyi vokal, berdasarkan posisi lidah termasuk dalam vokal depan dan belakang. Berdasarkan ketinggian lidah masuk dalam vokal tinggi, rendah dan tengah. Sedangkan berdasarkan posisi bibir termasuk dalam vokal bundar dan tidak bundar. (2) Proses penyederhanaan fonologis yang dihasilkan oleh subjek penelitian meliputi substansi atau penggantian vokal [æ] menjadi [a], bunyi [e] menjadi [i], bunyi dipthong [eI] menjadi [e]. Penyebab substansi bunyi vokal dikarenakan oleh posisi lidah dan ketinggian lidah saat mengucapkan bunyi yang tidak sesuai. Penyederhanaan struktur suku kata dengan cara mengambil suku kata terakhir dan mereduplikasinya dengan skturktur kata KVdengan rincian sebagai berikut [mama], [papa], [toto], [nana], [nono]. Hilangnya bunyi konsonan pada kata [halo] menjadi [ao]. Hilangnya bunyi konsonan [r] pada kata [ka:r] menjadi [ka:]. Hal ini disebabkan oleh belum mampunya subjek peneliti untuk menghasilkan bunyi tersebut. (3) Terdapat ujaran yang tidak mengalami proses penyederhanaan yaitu [pi:], [mamak], dan [bobok]. Hal ini tentu dikarenakan oleh kesiapan alat bicara anak dalam menghasilkan fonem /p/, /i/, /a/, /b/, /0/, dan $/ \mathrm{k} /$.

Dari hasil temuan tersebut, dapat dikatakan bahwa proses penyederhaan ujaran yang dihasilkan anak tentu akan berbeda tergantung kesiapan anak tersebut. Anak akan mengalami proses penyederhanan baik berupa substansi, reduksi maupun penyederhanaan struktur kata dalam pengucapan bunyi. Kanak-kanak akan memperoleh sistem fonologi seperti layaknya orang dewasa setelah melalui proses penyederhanaan, berupa penciptaan struktur sendiri olehnya. Peranan lingkungan, orang di sekitar sangat dibutuhkan sehingga anak tersebut nantinya akan mampu untuk mengahasilkan ujaran dan bahkan kalimat secara sempurna seperti yang seharusnya. Orang tua hendaknya jangan meniru bentuk sederhana yang diciptakan oleh anak, namun tetap memberikan contoh pengucapan kata yang sebenarny karena anak masih dalam 
proses meniru. Peranan orang tua juga sangat diharapkan jumlah dan jenis kata yang dihasilkan oleh anak tentu karena hasil stimulasi dari lingkungan sekitarnya.

\section{DAFTAR PUSTAKA}

Andini, H. (2018). Lingua. Lingua, 15(1), 4552.

https://doi.org/10.30957/lingua.v15i1.42 9.1.

Anggaira, A. S. (2016). Pemerolehan Fonologi Dan Metatesis: Studi Kasus Pada Anak Usia 2 Tahun 10 Bulan. Jurnal Pendidikan Bahasa Dan Sastra, 16(2), 213.

https://doi.org/10.17509/bs_jpbsp.v16i2 . 4483

Apriani, T., Santoso, A. B., \& Puspitasari, D. (2019). Pemerolehan Fonologi dan Leksikon pada Anak Usia 3.6 Tahun: Kajian Psikolinguistik. Widyabastra, 07(1), 9-17.

Arnawa, N. (2009). Bahasa Bali Usia AnakAnak: Kajian Metabahasa Semantik Alami. Linguistika, 16(30).

Budhiono, R. H. (2011). Pemerolehan Fonologis Pada Anak Usia 0-2 Tahun. Adabiyyāt: Jurnal Bahasa Dan Sastra, 10(1), 162. https://doi.org/10.14421/ajbs.2011.10108

Chaer, A. (2009). Psikologi Kajian Teoritik.
PT. Rineka Cipta.

Huber, M., Mukherjee Volume, J., \& Lang, P. (2009). Textbooks in English Language and Linguistics (TELL) Introduction to English Phonetics and Phonology.

Ingram, D. (1979). Phonological patterns in the speech of young children. In Language Acquisition. Studies in First Language Development ed. by P. Fletcher and M. Garman (pp. 133-148). Cambridge University Press.

Ingram, D. (1989). First Language Acquisition Method, Description and Explanation. Cambridge University Press.

Kridalaksana, H. (1984). Kamus Linguistik. Gramedia.

Palenkahu, H. (2009). Pemerolehan Bahasa Pertama Anak Kembar Usia Dua Tahun Delapan Bulan. Linguistika, 16(31).

Piaget, J. (2001). The language and thought of the child. Jean Piaget: Selected Works. Volume 5.

Saputri, R. (2018). Pemerolehan Bahasa Anak Usia 3 Tahun. Jurnal Linguistik, Sastra, Dan Pendidikan (Jurnalistrendi), 2(4), 210-214.

Suardi, I. P., Ramadhan, S., \& Asri, Y. (2019). Pemerolehan Bahasa Pertama pada Anak Usia Dini. Jurnal Obsesi: Jurnal Pendidikan Anak Usia Dini, 3(1), 265. https://doi.org/10.31004/obsesi.v3i1.160 